\title{
Ocorrência do Vírus da Pinta Verde em Maracujá no Estado do Maranhão, Brasil
}

\author{
Flávio H. R. Moraes ${ }^{1,2 *}$, Wenyo R. F. Belo ${ }^{1}$, Gilberto J. Moraes ${ }^{3}$ \& Elliot W. Kitajima ${ }^{3}$ \\ ${ }^{1}$ Depto. de Fitotecnia e Fitossanidade, Laboratório de Fitopatologia, UEMA, Cx. Postal 09, CEP 65054-970, São Luís- \\ MA; ${ }^{2}$ Professor Adjunto di Centro Universitário do Maranhão (UNICEUMA), e-mail: fhrmoraes@bol.com.br; ${ }^{3}$ Depto. \\ Entomologia, Fitopatologia e Zoologia Agrícola, ESALQ / USP, Cx. Postal 09, CEP 13418-900, Piracicaba, SP
}

(Aceito para publicação em 06/06/2005)

Autor para correspondência: Flávio H. R. Moraes

\begin{abstract}
Occurrence of Passion fruit green spot virus in the passion fruit crop in the State of Maranhão, Brazil

Yellow passion fruit (Passiflora edulis f. flavicarpa) plants with characteristic symptoms of the green spot disease (yellow fruits with green spots, necrotic lesions in the stems, green patches in senescent leaves) were observed in commercial fields in the State of Maranhão, associated with infestation by the tenuipalpid mite Brevipalpus phoenicis. Transmission electron microscopy was performed on tissue from the green spots of the fruits, revealing the presence of short bacilliform particles within endoplasmic reticulum cisternae and dense viroplasm in the cytoplasm, typical of the cytoplasmic type of Brevipalpus-borne viruses. This confirms that the causal agent of the disease was the Passion fruit green spot virus. This is the first report of this virus in the State of Maranhão.
\end{abstract}

O maracujá amarelo (Passiflora edulis Sims. f. flavicarpa Deg.) representa uma boa alternativa para pequenos produtores do Maranhão, sendo cultivado em várias regiões do Estado. Em visitas a áreas de produção de São Luís (Bom Jardim I e II, Itapera I, Jardim São Cristóvão II, Altos do Turu e Araçagy), Paço de Lumiar (Mercês e Maiobão), Açailândia e Santa Inês, notou-se a ocorrência de sintomas característicos da "pinta verde", causada por "Passion fruit green spot virus" (PGSV) transmitido pelo ácaro tenuipalpídeo Brevipalpus phoenicis Geijskes. Este vírus responsável por sérios prejuízos na região de Vera Cruz, SP, onde foi descrito pela primeira vez, já se acha constatado em outros estados brasileiros como DF, MG, RJ, SE, BA e RO (Kitajima et al., Exp. Appl. Acarology 30:225. 2003). Do total de dez campos visitados, em três (Itapera I, Araçagy e Santa Inês) foram observados sintomas em folhas e frutos, enquanto, em Mercês encontraram-se apenas frutos sintomáticos. Nas folhas jovens foram observadas lesões em forma de anéis concêntricos, clorose e áreas mais claras em torno das nervuras principais e secundárias (Figura 1A). Com o amadurecimento das folhas, os anéis, até então cloróticos, tornam-se verdes, contrastando com o amarelo do limbo (Figura 1B). Nos frutos maduros verificaram-se manchas verdes de pequeno diâmetro e contorno arredondado, contrastando com o amarelo intenso do resto da superfície dos frutos (Figura 1C). Nos ramos visualizaram-se lesões necróticas, alongadas, de crosta saliente que se juntaram, tornando-se pardo-escuras (Figura 1D). Esta condição foi particularmente intensa em Santa Inês, onde se verificou uma infecção severa com plantas secas e mortas devido a coalescência das lesões nos ramos e caule principal. Exames feitos em folhas coletadas em todas as áreas detectaram a presença

*Pesquisador - Bolsista BFP da FAPEMA de ácaros, identificados como B. phoenicis (Figura 1E). A população deste ácaro foi particularmente alta no período que antecedeu as chuvas. Exames ao microscópio eletrônico de transmissão de tecidos das manchas verdes dos frutos constataram a presença de grupos de partículas baciliformes no lúmen do retículo endoplasmático de células parenquimatosas (Figura $1 \mathrm{~F})$, além do viroplasma denso no citoplasma, característicos dos vírus transmitidos pelo ácaro do gênero Brevipalpus, do tipo citoplasmático (Kitajima et al., Exp. Appl. Acarology 30:135. 2003). A sintomatologia, a presença do ácaro vetor e a detecção de presumíveis partículas virais confirmam que o agente causal da enfermidade era o PGSV, sendo este o primeiro relato do vírus no Estado do Maranhão.

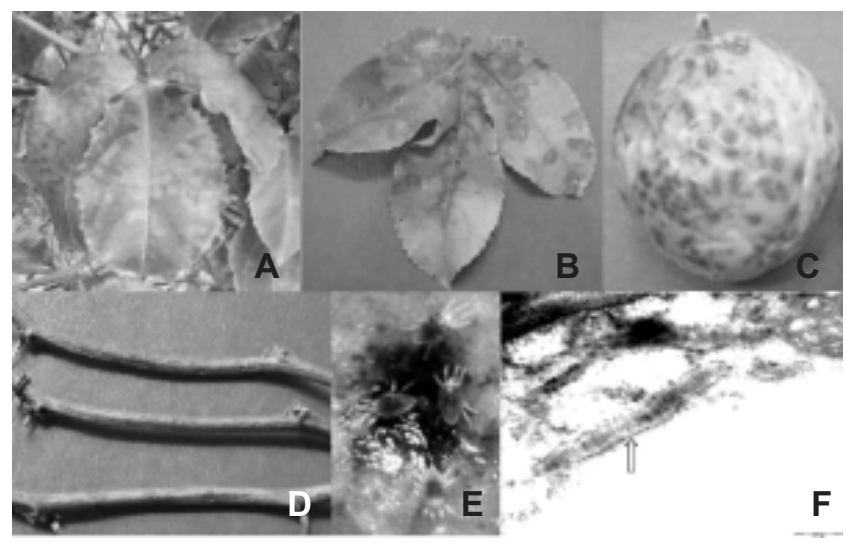

FIG. 1 - Folha nova (A) e velha (B) de maracujá amarelo (Passiflora edulis f. flavicarpa) apresentando sintomas de anéis; Fruto com pintas verdes na casca (C); Ramos com necrose (D). Vetor - ácaro Brevipalpus phoenicis (E); Fila de partículas baciliformes no lúmen do retículo endoplasmático (seta), em uma célula do córtex do fruto com sintoma (F). Barra $=200 \mathrm{~nm}$. 